Dr ČEDOMIR ANTIĆ, docent

Filozofski fakultet Univerziteta u Beogradu

Beograd, Čika Ljubina 18-20

chedomir.antic@gmail.com

prethodno saopštenje

UDK 94(497.11:496.5)"1912/1913"(093.2)

$355.355(=163.41) " 1912 / 1913 "(093.2)$

primljeno: 23. oktobar 2016.

prihvaćeno: 8 . februar 2017.

\title{
A PORT AND A RAILWAY: THE HISTORY OF A MARITIME COUNTY AS A STUDY OF BALKAN COLONIALISM 1912-1913*
}

\begin{abstract}
This article deals with a period of Serbian rule over the Northern Albanian districts (from November 1912 to April 1913). As Kingdom of Serbia was the only European country, beside Switzerland, with no territorial access to the open sea, one of its main war aims was the annexation of an outlet to the Southern Adriatic. Thus after the First Balkan War victory, Serbian army occupied some territories in Northern Albania which were not populated by ethnic Serbs, but were of utmost importance for the commercial and strategic reasons. In this article the colonial and imperial aspects of short-lived Serbian rule are examined and compared with the experience of colonial powers.
\end{abstract}

KEYWORDS: Serbia, Northern Albania, colonialism, Maritime district

At the beginning of the twentieth century, Serbia was struggling in order to maintain its political and economic independence. Threatened by both the Habsburg and Ottoman Empires, the success of this endeavour required unity with the peoples that lived in areas along its borders. The Austro-Hungarian monarchy frequently closed its borders to Serbian export in the decades that preceded the First World War. ${ }^{1}$ This policy resulted in two custom wars during the first decade of the twentieth century, which forced Serbia to find new export markets.

The Kingdom of Serbia entered the First World War as the only European state, (apart from neutral Switzerland), without direct access to the sea. Serbia was faced with the Austro-Hungarian occupation of Bosnia and Herzegovina, a prohibition on a planned union with Montenegro, and other pressures. Consequently, during

\footnotetext{
* Rad je deo projekta Srpska nacija - integrativni i dezintegrativni procesi, (177014), koji finansira Ministarstvo prosvete, nauke i tehnološkog razvoja Republike Srbije.

${ }^{1}$ Dimitrije Đorđević, „Sučeljavanje se Austro-Ugarskom“, u: Istorija srpskog naroda, VI/I, urednik Andrej Mitrović (Beograd: Srpska književna zadruga, 1994), 159; Vladimir Ćorović, Odnosi između Srbije i Austrije u XX veku (Beograd: Biblioteka grada Beograda, 1992).
} 
the negotiations over the creation of the Balkan League, Serbia began to plan the construction of an Adriatic Railway, through the territory of the Northern Albania, where Serbs and South Slavs were not the majority population. ${ }^{2}$

Many foreign authors, the most influential of which were Malcolm and Canon, have tried to present the First Balkans War and Serbia's action in the Western Balkans as the main cause of World War I, as well as a case of ethnic cleansing that went unpunished. ${ }^{3}$

According to this interpretation, Serbia's only motive was the creation of a large and ethnically clean nation-state. ${ }^{4}$ This interpretation is largely based on the secondary sources originating in Austria-Hungary, which was itself on the verge of war with Serbia during the Balkan Wars ${ }^{5}$. A study of the attitudes of Serbian politicians and intellectuals on the issue of Albanians and Albania shows that the predominant view was that it was a Serbian "mission of liberation", with only an occasional mention of an "occupation" of the Northern Albania. This is quite contrary to the theory of Serbian politics being exclusively concerned with creating a great nation state. ${ }^{6}$

At the beginning of the First Balkan War the territory of the Northern Albania fell under Serbian control after two Serbian army divisions defeated an Ottoman army during a two-week campaign. Serbian troops managed to conquer the area between the Prokletije Mountains and the Škumb and Drim rivers. This area remained under Serbian control between November 1912 and April 1913. Although historiography has previously presented this as an attempt to join this province to Serbia, by integrating it into a centralized structure (municipal-district-county), it is certain that the characteristics of a consistent policy towards Albania can be recognized continuously from 1912 to 1918.

The Maritime Area (according to some sources the County) established at the beginning of the war in October 1912 was divided into two counties - Lješki and Drački. Unlike the other new counties, their districts corresponded with the borders

${ }^{2}$ Mr Milić J. Milićević, „Albanska operacija 1912-1913. godine“, (doktorska disertacija, Univerzitet u Banjoj Luci, Filozofski fakultet, 2006), 16-54.

${ }^{3}$ Noel Malcolm, Kosovo: A Short History (London: Pan, 1998); Robert D. Kaplan, Balkan Ghosts: A Journey Through History (New York: St. Martin's Press, 1993). Miranda Vickers has not only missed to present the grounds for Serbian endeavours to get access to Adriatic coast, but explained relations between Serbs and Albanians by reducing them to the crimes that Serbian army implemented. Miranda Vickers, The Albanians, A Modern History (London: I. B. Tauris, 2001), $68-69$.

${ }^{4}$ Foreign observers exclusively wrote about persecution and ethnic hatred. The politics of Serbia and its Balkan allies was not placed in the context of contemporary policies of European states. Mary Edith Durham, Bejtullah Destani (edit.), Albania and the Albanians, Selected Articles and Letters, 19031944 (London: I. B. Tauris, 2005), 27-32. The important exception is the interpretation of Serbian socialdemocrat Dimitrije Tucović who claimed as early as 1914 that the only thing Serbia wanted in the war was "access to the sea and one colony of its own". Dimitrije Tucović, Srbija i Arbanija (Beograd, 1914 [1980], 62 .

${ }^{5}$ Leo Freundlich, Albaniens Golgotha: Anklageakten gegen die Vernichter des Albanervolkes (Wien: Josef Roller, 1913).

${ }^{6}$ Olivera Milosavljević, U tradiciji nacionalizma ili stereotipi o nama i drugima (Beograd: Helsinški odbor za ljudska prava u Srbiji, 2002). 
of Albanian tribes that lived in that territory ${ }^{7}$. On November 28th 1912, Ivan Ivanić and Sima Avramović were appointed as heads of the counties. The Serbian administration was small-scale and symbolic, and from the outset it faced numerous obstacles. The governments of the Great Powers, especially the British, demanded that Serbia should not establish a civil authority in Albania, out of deference to AustriaHungary ${ }^{8}$. Consequently, in the Maritime County the government itself immediately decided to make the civilian authorities subordinate to the military. Serbian authority was then established in the territories, which differed significantly from the other parts of the enlarged state, as these territories were considerably more impoverished.

The Serbian authorities began to seriously contemplate annexing the territories in question only in 1912, when their outlet to the sea through Skadar and the direct routes to the borders with Greece were cut-off.

At the beginning of the twentieth century over 272.000 inhabitants lived in the area which consisted of $10,500 \mathrm{~km}^{2} .{ }^{9}$ In October 1912, the London Times published maps of the territories that would later become independent Albania. Conditions there were such that the Ottoman authorities were unable to collect taxes in the areas that was going to become part of the Maritime County. In addition, it was impossible to disarm the local tribes, and to recruit the local population into the Ottoman army. The Serbian army tried to collect taxes and partially pacify the population. The new authorities did not manage to start the construction of the railway, but succeeded in establishing a telegraph connection. Guarding telegraph relay stations proved to be a difficult and dangerous task, in which a large number of Serbian soldiers were killed. ${ }^{10}$ In addition, the tax revenues proved to be unsatisfactory. ${ }^{11}$

The Serbian government tried on several occasions to communicate with the Albanians in Old Serbia (Kosovo and Metohija today) and Albania. The evolution of the Serbian government's stance towards the Arbanasi people can be traced in three documents, which originated in the Serbian government in official form in 1912, 1914 and 1915. Firstly, before the outbreak of the First Balkan War, the Prime Minister of the Kingdom of Serbia's government, Nikola Pašić, put forward a document entitled "A Contract of Community between Serbs and Arbanasi in Kosovo

${ }^{7}$ In that manner, Lješki county included Fandski district (Mirditi tribe with centre in town Oroši) and Dukadjini district (tribe Dukadjin, with centre in town Puka). M. J. Milićević, op. cit., 244. Milićević relied on military sources defining this territory was an area divided into two counties. The majority of other sources list that this territory became one of the counties (Maritime or Marine), that was divided into four districts (Drački, Tiranski, Lješki and Elbasanski). These data are contradictory mainly since the establishment of administration was temporary and incomplete.

${ }^{8}$ Михаило Војводић (прир.), Документа о спољној политици Краљевине Србије: 19031914, књ. 5, св. 3 (Београд: Српска академија наука и уметности, Одељење историјских наука, 1986), документ 408.

${ }^{9}$ Herders Konversations Lexikon, I, A bis Bonaparte (Freiburg im Breisgau: Verlag Herder, 1902), 996-997.

${ }^{10}$ M. J. Milićević, op. cit., 219.

${ }^{11}$ Exact registration of military commands proves that the Drina division in the area of Zadrimlje managed to collect almost close to 20.000 dinars, where less than $7 \%$ was directed in the budget on the basis of the central tax - desetak. The expenditure of this division, during the sixmonth stay in Albania, reached twenty-one times as high a price, climbing up to the amount of 424.000 dinars! 
Vilâyet". ${ }^{12}$ However, this offer was regarded as insincere, as at that time Constantinople and Vienna undoubtedly had a greater influence over Albanian leaders than Belgrade. As the Serbian army had to take control over Kosovo Vilâyet and the coastal area by force, the Arbanasi were not granted with the status that had been previously offered. However, the Serbian administration in Albania took a different stance towards the local population, which was ethnically more monolithic than in area east of the Prokletije Mountains. ${ }^{13}$

In December 1912 Serbia had already accepted the inevitable existence of an Albanian state. With the assistance of foreign intervention and arbitration, the mapping of borders was implemented in 1914. An invasion by Arbanasi units in the area of Debra in 1913 and the commencement of the First World War persuaded Serbian officials to try to pacify or at least secure the south-western border of their country. A secret agreement was made between Serbia and Albania on September 17, 1914 in Niš, after negotiations between the Serbian government and Essad Pasha, the former Ottoman general, protector of Skadar and one of the ruling powers in Albanian state. $^{14}$

Besides the provisions concerning common defence, Serbian officials accepted a change to their previous position on the issue of the independence and neutrality of the Albanian monarchy. ${ }^{15}$ Finally, point 11 of the agreement bound Essad Pasha not to oppose the construction of the Adriatic railway to Durazzo (Dures), while Serbia would reimburse the owners of land expropriated for the construction of the railway. Essad Pasha agreed to closely cooperate with all future official representatives of Kingdom of Serbia in Albania.

Essad Pasha succeeded in taking control over Central Albania with the help of Serbia and appointing himself as its master. However, the Ottoman Empire entered the First World War and the difficulties that Serbia then faced in the war with Austria-Hungary resulted in a tide of uprisings in Central Albania at the end of 1914. Only the intervention of the Serbian army at the beginning of 1915 and occupation of strategic points in Albania enabled the uprising to be suppressed. At the end of June 1915, in Tirana, Ljuba Jovanović, special envoy of Serbian Prime minister Pašić, had

${ }^{12}$ Đorđe Stanković, „Nikola Pašić i stvaranje albanske države“, u: Iskušenja jugoslovenske istoriografije (Beograd: Rad, 1988), 231; Miloš Jagodić, Srpsko-albanski odnosi u kosovskom vilajetu (1878-1912) (Beograd: Zavod za udžbenike, 2009), 361. By the letter of this document if the Albanians would join Kingdom of Serbia, as in the case of Kosovo vilâyet, they would be granted with "freedom of religion, Albanian language in schools, in judiciary authorities, in administration of their municipalities and districts, their old judicial customs, special Albanian assembly that would vote the decisions on the religious, educational and judiciary matters“.

${ }^{13}$ Г. Тодоровски (прир.), Српски извори за историјата на македонскиот народ 1912-1914 (Скопје: Институт за национална историја, 1979), 54-55.

${ }^{14}$ This former Ottoman general, Albanian sovereign and competitor of Wilhelm Wied for the Albanian throne received full support from the Serbian government for taking over the power in Albania. In return, relations between two countries and Serbian influence in Albania were defined in 15 points. Dušan T. Bataković, Kosovo i Metohija u srpsko-arbanaškim odnosima (Beograd: Čigoja štampa, 2006), 209-210.

${ }^{15}$ Up to some later period, the new border was really established. New border was supposed to be defined by the Serbian-Albanian committee, instead of former committee made of representatives of Great Powers. 
made a new secret arrangement with Essad Pasha. More detailed than the previous contract, this agreement stipulated specific redrawing of the borders, assistance for Essad Pasha's Government and establishment of a "real union" between the two states. Point 8 of the agreement specified that army, customs, diplomacy, finance, trade and traffic will be unified. This time, there was no mention of the construction of the railway. ${ }^{16}$

Comparative analysis of these examples and examples of European colonial practice, including the Austro-Hungarian endeavours to transform Balkan countries into political satellites, cannot lead us to precise conclusions. Although since Gibbon's time Albania was compared to unexplored areas of America, ${ }^{17}$ even the most radical Serbian intellectuals did not find it easy to justify the constant negation of the Albanian's rights to their national identity and ultimately, their own state.

Serbia had from the very outset, i.e. since a contract was offered in September 1912, considered the possibility of organising a form of self-government for Albanians, with the involvement of the Serbian state, but independent in religious, education and judicial matters. This gives rise to a comparison with the self-government that Great Britain tried to negotiate with the Irish from the 1880's until the First World War. Although Ireland was under English rule for seven centuries, integration of these two nations never occurred and religious differences gained political significance over time.

In the same way that the proposal of 1912 did not differentiate between ethnically mixed areas of what is today Kosovo and Metohija and the Northern Albania, (for which Serbia had aspirations as well), the new law on self-government ${ }^{18}$ that $^{2}$ Gladstone presented on April $8^{\text {th }}, 1886$ proposed autonomy for the entire island of Ireland. However, since Ireland had its own Parliament and a certain amount of autonomy since 1800, this project gave away a lot more powers than Pašić's succinct proposal of autonomy for the Kosovo Vilâyet. An assembly was supposed to be established in Ireland, not following in the tradition of the former parliament, but with the central government retaining power over defence, trade, foreign policy and temporary administration of the police. Executive power was exercised by the Lord Lieutenant of Ireland $^{19}$. The range of powers to be retained was similar to the role

${ }^{16}$ Because of the war time, they only took into consideration the construction of the road from Tirana to Drach. D. T. Bataković, op. cit., 215-216; One should mention that during Serbian retreat through Albania, Arbanasi population sometimes gave their opinion on the relation between two states. In diary of Milivoj Mladjenović, a Serbian officer, one can read that he would meet Arbanasi who used to say: "Essad Pasha and King Peter barabar - equal". Nedeljko Ješić, Dragica Matić i Vidan Nikolić, Ratni dnevnici Užičana 1912-1918 (Užice: Istorijski arhiv Užice, 1995), 143.

17 "...a country within sight of Italy, which is less known than the interior of America". Norman Davies, Europe: A History (Oxford: Oxford University Press, 1996), 645.

${ }^{18}$ The first Home Rule Bill, officially Irish Government Bill.

${ }^{19}$ Alvin Jackson, Home Rule: An Irish History 1800-2000 (Oxford/New York: Weidenfeld, 2003), 67-70. One should note that this proposal was overruled in British Parliament, which had a consequence of Gladstone government (cabinet) collapse. Self-government for Ireland was implemented only in 1914, as the power of the House of Lords was diminished (1911). The price of its implementation was the political division of the island. The war disabled and postponed the establishment of the selfgovernment. A. T. Q. Stewart, The Ulster Crisis, Resistance to Home Rule, 1912-14 (New York: Faber and Faber, 1967), 58-68. 
that Serbia planned for itself in the Niš agreement in 1914 and Tirana protocol in 1915.

The conditions and the provisions of Agreement of Bordeaux which established the French protectorate in Tunisia on May 12th 1881 has many similarities with the Niš agreement in 1914. The cause of the French army entering the territory of Tunisia was an incursion by one Tunisian tribe into Algeria. ${ }^{20}$ Once the resistance of Tunisians was crushed, the protectorate was established and it existed for more than seventy years. By the letter of the agreement, France took over the responsibility for Tunisian defence and foreign policy. Besides railways, the construction of which played a very important role in the French politics of West Africa, colonial authorities were dealing with programmes of public health, hygiene and education ${ }^{21}$. Serbia's readiness to grant judicial autonomy to the Albanian tribes is comparable with France's granting of judicial authority to the traditional courts in West Africa in 1912. ${ }^{22}$ Unlike the French authorities, the Serbian authorities showed no intention of economically exploiting the already impoverished population of the Maritime County. ${ }^{23}$

Another significant feature of French colonialism, which could have influenced the Kingdom of Serbia in the formulation of its own policy objectives towards Albania during the second decade of the twentieth century, was the policy of assimilation. Although the Serbian state did not manage to establish permanent and consolidated authority in Albania, it is certain that many Serbian intellectuals regarded the establishment of Serbian authority in new areas as the liberation of all of their inhabitants. The ideological foundation of French colonialism was represented by the powerful belief in the civilizing mission that would in time transform the population in the colonies first into French citizens, and then Frenchmen. ${ }^{24}$ In Serbia this belief was founded on the real and alleged state tradition and ethnic background of the Albanians. ${ }^{25}$ Authors naturally mentioned political and economic reasons for taking control of Albania, which were more compelling and dramatic than those talked about in trade circles in French coastal towns, especially Marseilles. Since the beginning of twentieth century, they wrote of the "suffocation" of Serbia, enclosed by narrow borders and separated from free access to world markets, as "tuberculous" and dying. ${ }^{26}$ Access to the sea represented "lungs" for the "besieged country" and its "incarcerated people". ${ }^{27}$ Vladan Đorđević, the conservative former Serbian Prime Min-

${ }^{20}$ For similar reasons the interventions of Serbian army in Albania were initiated in the dawn of and during First World War, as assistance to Essad Pasha which was one of the instruments of influence and intervention.

${ }^{21}$ Alice L. Conklin, "Colonialism and Human Rights, A Contradiction in Terms? The Case of France and West Africa, 1895-1914”, The American Historical Review, vol. 103, no. 2 (Apr, 1998), 431.

${ }^{22}$ Ibid., 436.

${ }^{23}$ Ibid., 438.

24 "Mission civilisatrice". Martin D. Lewis, "One Hundred Million Frenchmen: The "Assimilation" Theory in French Colonial Policy", Comparative Studies in Society and History, vol. 4, no. 2. (Jan, 1962), 129-153.

${ }^{25}$ O. Milosavljević, op. cit., 124-125.

${ }^{26}$ New Myrmidon, 1902, 5.

${ }^{27}$ Jovan Cvijić, Der Zugang Serbiens zur Adria (Gotha: s. n. 1912), 12. 
ister, called Albanians "European redskins". Disapproving of the new nation and its right to a state, Đorđević believed that the obstacles to them establishing a civilisation were surmountable: "only a foreign country could create some order in Albania and try to make a nation out of Albanians." The process of national modernisation would, in Đorđević's opinion, still be "at the level of prehistoric development", and should last for at least one hundred years. ${ }^{28}$

Influences of more recent Italian colonial practice seems far more vivid. In the same way that Serbian independence was endangered from its very establishment in 1878 , the position of Italy as a Great Power was uncertain since Cavour's time. To strengthen their position, both countries had to do something. Serbia needed access to the sea, Italy wanted colonies. In the same manner that Serbia unwillingly chooses access to the Adriatic Sea through the Northern Albania (south of the river Drim), several months before the establishment of the Balkan League ${ }^{29}$, Italy was committed to the invasion of Libya due to pressure from its nationalist and clerical intelligentsia. ${ }^{30}$ The administration Italy established had similarities with the buds of the Serbian administration in the Maritime County. However, unlike Serbia, which wanted to annex a territorial access to the sea and had no desire or ability to colonise the conquered area, Italy massively colonised Libya during the decade of its administration. Planned tribal self-government was similar in both cases. The two models of colonialism differed in methods: unlike the Italian, the Serbian did not meet general opposition in the area. During ten years of the Serbian army's presence, violence in the area was neither frequent nor systematic as it was Italian in Libya. ${ }^{31}$ Serbia's inability to keep waste areas of the Northern Albania, pressure from Austria-Hungary and the Great Powers, and its economic weakness, led to abandoning the Northern Albania. Serbian politicians and intellectuals were partly right: for various reasons, not only due to the pressure from their neighbours, in decades to come Albania was the scene of disorder and anarchy. This would be partially changed only when in late 1920s, in the period between the two wars, Albania became an Italian satellite.

Serbia suffered great loss in the First World War, and it regained its sovereignty as part of the Yugoslavian monarchy that owned vast areas of the Adriatic coast and had economic access to the Aegean Sea. However, fresh Serbian colonialism was frustrated at its beginnings. It became obvious in the summer of 1915, during negotiations on the borders of the future expanded Serbian or united Yugoslav state. In the headquarters of the Serbian army, the concessions that were offered to Serbia (on the Albanian and generally Adriatic coast) were rejected, with the claim that since Italy occupied Vlore, Adriatic Sea was transformed into "Italian lake". ${ }^{32}$

${ }^{28}$ Vladan Đorđević, Arnauti $i$ Velike sile (Beograd: Izdavač trgovina Jevte M. Parlovića i kompanija, 1913), 97-104, 111, 141-142.

${ }^{29}$ After annexing of Bosnia and Herzegovina to the Austria-Hungary, the territorial access to the north was completely disabled, Austria-Hungary and agreement with Montenegro ruled out Bar or Skadar direction.

${ }^{30}$ Enrico Cravetto (ur.), Kolonijalna carstva i imperijalizam 1871-1914, Povijest, knj. XV, (Zagreb: Europapress holding, 2008), 382-383.

31 War in Balkans, HC Deb 13 February 1913, vol. 48, cc 1157-1159.

32 Čedomir Antić, Neizabrana saveznica: Velika Britanija i Srbija u Prvom svetskom ratu (Beograd: Zavod za udžbenike, 2012), 169. 
Albania thus ceased to be a priority of Serbian foreign policy, and the area of Old Serbia (Kosovo and Metohija) became a negligible periphery of the state. Thus the assimilation of the Slav population in the north of Albania increased. Regardless of conflicts and occasional Yugoslav and Serbian pressures on the national minorities, this allowed Kosovo and Metohija to become a monolithic ethnic Albanian territory.

\section{IZVORI I LITERATURA}

- New Myrmidon, 1902.

- War in Balkans, HC Deb 13 February 1913, vol. 48.

- Војводић, Михаило (прир.). Документа о спољној политици Краљевине Србиje: 1903-1914, књ. 5, св. 3. Београд: Српска академија наука и уметности, Одељење историјских наука, 1986.

- Тодоровски, Г. (прир.). Српски извори за историјата на македонскиот народ 1912-1914. Скопје: Институт за национална историја, 1979.

- Antić, Čedomir. Neizabrana saveznica: Velika Britanija i Srbija u Prvom svetskom ratu. Beograd: Zavod za udžbenike, 2012.

- Bataković, Dušan T. Kosovo i Metohija u srpsko-arbanaškim odnosima. Beograd: Čigoja štampa, 2006.

- Conklin, Alice L. "Colonialism and Human Rights, A Contradiction in Terms? The Case of France and West Africa, 1895-1914". The American Historical Review, vol. 103, no. 2 (Apr, 1998), 419-442.

- Cravetto, Enrico (ur.). Kolonijalna carstva i imperijalizam 1871-1914. Povijest, knj. XV. Zagreb: Europapress holding, 2008.

- Cvijić, Jovan. Der Zugang Serbiens zur Adria. Gotha: s. n. 1912.

- Ćorović, Vladimir. Odnosi između Srbije i Austrije u XX veku. Beograd: Biblioteka grada Beograda, 1992.

- Davies, Norman. Europe: A History. Oxford: Oxford University Press, 1996.

- Durham Mary Edith, and Bejtullah Destani (edit.). Albania and the Albanians, Selected Articles and Letters, 1903-1944. London: I. B. Tauris, 2005.

- Đorđević, Dimitrije. „Sučeljavanje sa Austro-Ugarskom“. U: Istorija srpskog naroda, VI/I. Urednik Andrej Mitrović. Beograd: Srpska književna zadruga, 1994.

- Đorđević, Vladan. Arnauti i Velike sile. Beograd: Izdavač trgovina Jevte M. Parlovića i kompanija, 1913.

- Freundlich, Leo. Albaniens Golgotha: Anklageakten gegen die Vernichter des Albanervolkes. Wien: Josef Roller, 1913.

- Herders Konversations Lexikon, I, A bis Bonaparte. Freiburg im Breisgau: Verlag Herder, 1902.

- Jackson, Alvin. Home Rule: An Irish History 1800-2000. Oxford/New York: Weidenfeld, 2003.

- Jagodić, Miloš. Srpsko-albanski odnosi u kosovskom vilajetu (1878-1912). Beograd: Zavod za udžbenike, 2009. 
- Ješić Nedeljko, Matić Dragica, i Vidan Nikolić. Ratni dnevnici Užičana 19121918. Užice: Istorijski arhiv Užice, 1995.

- Kaplan, Robert D. Balkan Ghosts: A Journey Through History. New York: St. Martin's Press, 1993.

- Lewis, Martin D. "One Hundred Million Frenchmen: The "Assimilation" Theory in French Colonial Policy". Comparative Studies in Society and History, vol. 4, no. 2. (Jan, 1962), 129-153.

- Malcolm, Noel. Kosovo: A Short History. London: Pan, 1998.

- Milićević, mr Milić J. „Albanska operacija 1912-1913. godine“. Doktorska disertacija. Univerzitet u Banjoj Luci, Filozofski fakultet, 2006.

- Milosavljević, Olivera. U tradiciji nacionalizma ili stereotipi o nama i drugima. Beograd: Helsinški odbor za ljudska prava u Srbiji, 2002.

- Stanković, Đorđe. „Nikola Pašić i stvaranje albanske države“. U: Iskušenja jugoslovenske istoriografije. 225-238. Beograd: Rad, 1988.

- Stewart, A. T. Q. The Ulster Crisis, Resistance to Home Rule, 1912-14. New York: Faber and Faber, 1967.

- Tucović, Dimitrije. Srbija i Arbanija. Beograd, 1914 [1980].

- Vickers, Miranda. The Albanians, A Modern History. London: I. B. Tauris, 2001.

Čedomir Antić

\section{LUKA I ŽELEZNICA: ISTORIJA PRIMORSKOG OKRUGA KAO OGLED BALKANSKOG KOLONIJALIZMA 1912-1913.}

\section{Rezime}

Srbija se početkom 20. veka borila da održi svoju političku i ekonomsku nezavisnost. Kada je Kraljevina Srbija ušla u Prvi svetski rat bila je jedina evropska država (osim neutralne Švajcarske), bez direktnog pristupa moru. Zato je Srbija, čak i pre pregovora o stvaranju Balkanskog saveza, počela da planira izgradnju jadranske pruge kroz teritoriju severne Albanije, gde Srbi i Južni Sloveni nisu bili većina. Na početku Prvog balkanskog rata teritorija severne Albanije je došla pod srpsku kontrolu nakon što su dve divizije srpske vojske porazile otomansku vojsku tokom dvonedeljne kampanje. Primorsko područje (prema drugim izvorima pokrajina) koje je osnovano na početku rata u oktobru 1912, bilo je podeljeno na dve pokrajine Lješki i Drački okrug. Srpska Vlada je pokušala u nekoliko navrata da kontaktira sa Albancima u Staroj Srbiji (danas Kosovo i Metohija) i Albaniji. U decembru 1912. Srbija je već prihvatila neizbežno postojanje albanske države. Primorska oblast je ostala pod srpskom kontrolom od novembra 1912. do aprila 1913. Promena pozicije srpske Vlade prema arbanaskom narodu može se naći u tri zvanična dokumenta Vlade Srbije u 1912, 1914. i 1915. Prvo, pre izbijanja Prvog Balkanskog rata, premijer Kraljevine Srbije Nikola Pašić predstavio je dokument pod nazivom „Sporazum o udruživanju između Srba i Albanaca u vilajetu Kosovo“. Nesposobnost Srbije da zadrži izolovanu teritoriju u severnoj Albaniji, pritisak Austro-Ugarske i 
velikih sila na nju i njene ekonomske slabosti, navele su je da napusti severnu Albaniju. Srpski političari i intelektualci su bili delimično u pravu: iz različitih razloga, a ne samo zbog pritiska suseda, Albanija je decenijama bila poprište nereda i anarhije. To se delimično promenilo kada je krajem 1920. Albanija postala satelit Italije u međuratnom periodu.

KLJUČNE REČI: Srbija, severna Albanija, kolonijalizam, Primorski okrug

\section{UN PORT ET UNE VOIE DE CHEMIN DE FER: HISTOIRE D'UNE PROVINCE MARITIME COMME ETUDE DU COLONIALISME DANS LES BALKANS \\ $1912-1913$}

\section{Résumé}

La Serbie, au début $\mathrm{du} \mathrm{XX}^{\mathrm{e}}$ siècle, se battait pour conserver son indépendance politique et économique. Quand le royaume de Serbie entra dans la Première Guerre Mondiale, il était le seul état européen (à part la Suisse neutre) n'ayant pas d'accès direct à la mer. En conséquence, même avant les négociations sur la création de la Ligue balkanique, la Serbie commença à planifier la construction d'un chemin de fer de l'Adriatique, à travers le territoire de l'Albanie du nord, où les Serbes et les Slaves du sud n'étaient pas majoritaires. Au début de la première guerre des Balkans le territoire de l'Albanie du nord tomba sous contrôle serbe après que deux divisions armées serbes aient défait l'armée ottomane au cours d'une campagne de deux semaines. La zone maritime (selon d'autres sources la province) établie au début de la guerre, en octobre 1912, était divisée en deux provinces - Ljeshki et Drachki okrug. Le gouvernement serbe essaya à plusieurs occasions de communiquer avec les Albanais en Vieille Serbie (le Kosovo et la Métochie d'aujourd'hui) et en Albanie. En décembre 1912 la Serbie avait déjà accepté l'existence inévitable d'un état albanais. La zone maritime resta sous contrôle serbe de novembre 1912 à avril 1913. L'évolution de la position du gouvernement serbe envers le peuple des Arbanases peut être retrouvée dans trois documents officiels du gouvernement serbe en 1912, 1914 et 1915. Tout d'abord, avant le déclenchement de la première guerre des Balkans, le premier ministre du Royaume de Serbie, Nikola Pašić, présenta un document intitulé "Contrat d'association entre les Serbes et les Arbanases dans le vilayet de Kosovo". L'incapacité de la Serbie à tenir les terres désolées de l'Albanie du nord, la pression sur elle de l'Autriche-Hongrie et des grandes puissances, ainsi que sa faiblesse économique, l'ont conduite à abandonner l'Albanie du nord. Les politiciens et intellectuels serbes avaient partiellement raison: pour différentes raisons, et pas seulement la pression des voisins, l'Albanie fut le théâtre de désordres et d'anarchie pendant des décennies. Cela changea en partie quand, à la fin des années 1920, l'Albanie devint un satellite de l'Italie dans l'entre-deux-guerres.

MOTS-CLÉS: La Serbie, l'Albanie du nord, colonialisme, La zone maritime 